\title{
Skrb vzbujajoče spremembe v mobilnosti mladih - primer osnovnošolcev $v$ Novem mestu
}

Tema prispevka so potovalne navade mladih v Sloveniji $\mathrm{v}$ zadnjih tridesetih letih in poskus pojasnitve razlogov za njihove popolnoma spremenjene potovalne vzorce. $\mathrm{V}$ prispevku se osredotočamo na potovalne navade osnovnošolcev, ki so posebna skupina udeležencev v prometu in uporabnikov mestnega prostora. Primerjamo podatke iz let 1991, 2001 in 2016 o potovalnih navadah osnovnošolcev, lastništvu osebnih avtomobilov, lokacijah osnovnih šol in velikosti šolskih okolišev ter prometni ureditvi v okolici osnovnih šol. V prispevku ugotavljamo, da rezultati v Sloveniji sovpadajo z ugotovitvami iz tujine. Velike spremembe $\mathrm{v}$ potovalnih vzorcih otrok časovno sovpadajo $\mathrm{z}$ intenzivno motorizacijo slovenskih mest, ki je dosegla večje razsežnosti kot v marsikateri razvitejši državi. Povečano lastništvo avtomobilov se kaže v njihovi povečani rabi. Aktivnosti, ki trenutno potekajo na šolah na področju urejanja prometa, ne prispevajo $k$ ustavitvi tega trenda. Potrebna bo sprememba v paradigmi prometne varnosti. Ukvarjanje z mobilnostjo otrok mora postati del celostnega prometnega načrtovanja, ki si mora prizadevati za zmanjšanje in umirjanje osebnega motornega prometa $\mathrm{v}$ okolici šol z vzpostavljanjem razmer, ki niso prijazne uporabi osebnih motornih vozil in spodbujajo varno rabo aktivnih alternativ.

Ključne besede: aktivna mobilnost, poti v šolo, spremembe potovalnih vzorcev, prometna varnost, motorizacija 


\section{Uvod}

Aktivna mobilnost ljudi, pri kateri za premikanje uporabljamo le telesno aktivnost, je že desetletja v ospredju prizadevanj za trajnostno mobilnost. Gre namreč za najbolj trajnostno obliko mobilnosti, ki je okoljsko najmanj sporna, ekonomsko najracionalnejša in socialno najbolj pravična. Je tudi najbolj zdrava, saj imata redna hoja in kolesarjenje številne pozitivne vplive na zdravje ljudi. Za mnoge je aktivna mobilnost najpreprostejši in najbolj dosegljiv način ohranjanja zdravega življenja, katerega temelj je vsaj polurna zmerna dnevna aktivnost (UK active, 2017). Razlog za številne hude zdravstvene težave, $s$ katerimi se srečujemo zaradi sodobnega sedečega življenjskega sloga, je pomanjkanje telesne aktivnosti. Zdravstveni strokovnjaki opozarjajo, da s tem, ko se ne gibamo, povečujemo tveganje za nastanek raznih bolezni. $\mathrm{Z}$ aktivnejšim življenjem pomembno zmanjšamo nevarnost za bolezni srca in ožilja, zmanjšamo možnost tveganja za kap in znižamo krvni tlak ter raven holesterola. Gibanje lahko prepreči tudi sladkorno bolezen tipa 2, celo raka na dojki in prostati. Z aktivnim načinom življenja ohranjamo zdravje mišic in skeleta (Ministrstvo za zdravje, 2015).

Posebno pereče so težave, ki jih imajo zaradi neaktivnega življenjskega sloga mladi in otroci. Delež čezmerno hranjenih in debelih otrok in mladostnikov se je namreč v zadnjih tridesetih letih podvojil, bolj izrazito je bilo to povečanje pri fantih, saj se je delež čezmerno težkih dečkov povečal s 13,3\% na 19,9\%, delež debelih pa se je povečal z 2,7 \% na 7,5\% (Ministrstvo za zdravje, 2015: 11). K porastu debelosti med mladimi poleg neustrezne prehrane veliko prispeva tudi njihova vse manjša telesna aktivnost. Raziskave v Sloveniji kažejo, da je delež redno telesno aktivnih mladih pri nas majhen in $\mathrm{s}$ starostjo še upada. Dnevno je dovolj telesno aktivnih $26 \%$ fantov in le $15 \%$ deklet (Jeriček Klanšček idr., 2011). Neustrezna prehranjenost otrok in mladine se kaže tudi v njihovi gibalni neučinkovitosti (Strel idr., 2011). Podatki kažejo, da so po drugi strani gibalno učinkovitejši mladostniki akademsko uspešnejši (Starc, 2014).

Tako kot pri odraslih lahko tudi pri mladih aktivna mobilnost pomembno prispeva $\mathrm{k}$ zagotavljanju zadostne dnevne telesne aktivnosti. Več avtorjev (Davison idr., 2008; Van Sluijs idr., 2009; Grize idr., 2010; Chillon idr., 2011; Schoeppe idr., 2012) v svojih študijah ugotavlja neposredno povezavo med tem, da otroci hodijo ali kolesarijo $\mathrm{v}$ šolo, in njihovo telesno zmogljivostjo. Ugotavljajo tudi močno povezavo med aktivnim prihodom $\mathrm{v}$ šolo in telesno aktivnostjo otrok zunaj šolskega časa v popoldanskih urah. Aktivna mobilnost zagotavlja tudi neodvisno mobilnost, ki jo Stephanie Schoeppe s sodelav- ci (2012) opredeljuje kot možnost mladih, starih do 18 let, da se gibajo in uporabljajo javni prostor brez nadzora staršev. Otroku zagotavlja psihosocialne koristi v družbenih interakcijah in povezovanju z vrstniki in drugimi prebivalci okolja, $\mathrm{v}$ katerem živijo.

O tem, kakšna je mobilnost mladih v Sloveniji in kako se je njihov način potovanj spreminjal zadnja desetletja, podatkov skoraj ni. Nekaj novejših raziskav (Kobe Tavčar, 2015; Moscholidou in Colclough, 2017) opozarja, da je v Sloveniji kar tri četrtine osnovnošolcev v šolo pripeljanih, večina z osebnim avtomobilom. Nasprotno rezultati Popisa prebivalcev iz leta 1991 kažejo popolnoma drugačno podobo. Takrat je velika večina (nad $90 \%$ ) osnovnošolcev in srednješolcev v šolo prihajala aktivno. Osrednja tema tega prispevka je ugotoviti, kaj se je dogajalo z mobilnostjo otrok $\mathrm{v}$ zadnjih tridesetih letih $\mathrm{v}$ Sloveniji in kateri so razlogi za njihove popolnoma spremenjene potovalne vzorce.

V prispevku se osredotočamo na potovalne navade osnovnošolcev, ki so posebna skupina udeležencev v prometu in uporabnikov mestnega prostora. Zaradi mladosti imajo omejeno možnost izbire načina potovanj in šele $\mathrm{v}$ času šolanja postanejo samostojni udeleženci v prometu. So ena najbolj ogroženih skupin prebivalcev zaradi prometa, zato jim prometno in prostorsko načrtovanje namenjata posebno pozornost (Plevnik, 2002). Analizirali smo način prihoda $\mathrm{v}$ osnovno šolo $\mathrm{v}$ Novem mestu v treh časovnih prerezih - v letih 1991, 2001 in 2016. Podatki za leto 1991 so bili zbrani v popisu prebivalstva leta 1991, z anketo po osnovnih šolah pa smo dobili podatke za leti 2001 in 2016. Hkrati smo za leti 2001 in 2016 zbrali dodatne podatke, $s$ katerimi v razpravi poskušamo pojasniti, kaj je povzročilo velike spremembe potovalnih navad osnovnošolcev in kateri so možni pristopi za povečanje aktivne mobilnosti med to populacijo.

\section{Metoda}

Spremembe potovalnih navad osnovnošolcev v Novem mestu smo analizirali $\mathrm{z}$ empirično raziskavo, in sicer $\mathrm{z}$ analizo časovnih prerezov in navzkrižno analizo. $\mathrm{Z}$ analizo časovnih prerezov smo ugotavljali spremembe potovalnih navad med časovnima prerezoma (2001 in 2016). Rezultate teh časovnih prerezov smo primerjali še $\mathrm{z}$ rezultati popisa prebivalstva iz leta 1991 (Zavod Republike Slovenije za statistiko, 1992). Z navzkrižno analizo smo ugotavljali, kako je variiranje spremenljivk potovalnih navad povezano z variiranjem družbenoekonomskih spremenljivk (lastništvo osebnih avtomobilov) in spremenljivk fizične zgradbe mest (razmestitev šol, velikost šolskega okoliša, prometne ureditve v okolici šol). 


\subsection{Potovalne navade osnovnošolcev}

Prvi časovni prerez potovalnih navad osnovnošolcev (skupaj s srednješolci) v Novem mestu predstavljajo rezultati popisa prebivalstva leta 1991. Obdelani so bili v doktorski disertaciji (Plevnik, 2002) in temeljijo na odgovorih na vprašanja iz popisa prebivalstva leta 1991 o kraju dela in šolanja ter o načinu poti (Zavod Republike Slovenije za statistiko, 1992). Iz individualnih podatkov o poteh $\mathrm{v}$ šolo so bili izbrani tisti, ki so se nanašali na poti osnovnošolcev in srednješolcev z začetkom in ciljem v Novem mestu. Z obdelavo podatkov so bili izlušceni podatki o načinu poti v šolo v naseljih stalnega bivališča. Žal podatkov za osnovnošolce ni bilo mogoče izločiti iz podatkov vseh poti v šolo, kljub temu tudi združeni podatki v obravnavanih naseljih prikazujejo potovalne navade mladih leta 1991.

Drugi časovni prerez potovalnih navad osnovnošolcev v Novem mestu predstavljajo podatki iz leta 2001, zbrani za doktorsko disertacijo (Plevnik, 2002). Zbiranje podatkov je izhajalo iz raziskave »Državne ceste in prometna varnost učencev « (Polič idr., 2001), ki so jo izvedli na osnovnih šolah v desetih naseljih v Sloveniji, med njimi tudi na OŠ Center v Novem mestu. Podatke o potovalnih navadah in rezultatih proučitve razmer v okolici OŠ Center smo v disertaciji prevzeli iz omenjene raziskave, obravnavo pa razširili še na dve osnovni šoli v Novem mestu - Bršljin in Grm. Anketirali smo učence 3., 5. in 7. razreda obeh osnovnih šol. V vseh razredih je postopek izpolnjevanja pisne ankete vodil anketar ob pomoči učiteljev v razredu, učenci pa so sami izpolnjevali vprašalnike. Učenci so označili spol, najpogostejši način poti $\mathrm{v}$ šolo in iz šole, morebitno spremstvo na poti v šolo in iz šole ter na karti označili lokacijo bivanja. Učenci nižjih razredov so prosili za podrobnejšo razlago ter sprotno preverjanje razumevanja vprašanj in pravilnega izpolnjevanja ankete. Anketiranje je potekalo 10. aprila $2001 \mathrm{v}$ dopoldanskih urah. Vreme tega dne je omogočalo uporabo vseh potovalnih načinov. Tudi anketiranje, ki so ga izvedli na OŠ Center, je potekalo v razredu med poukom. $\mathrm{V}$ anketo so vključili tudi učence 1 . razreda. $\mathrm{V}$ višjih razredih (3., 5. in 7. razred) je bil vprašalnik obsežnejši in je vključeval še vprašanja o prometni varnosti.

Drugo anketiranje o potovalnih navadah je potekalo junija 2016 med analizo stanja za celostno prometno strategijo Mestne občine Novo mesto (Balant idr., 2017). V anketiranje je bilo vključenih sedem osnovnih šol v Mestni občini Novo mesto, štiri iz Novega mesta (Center, Šmihel, Grm in Bršljin) in tri iz manjših naselij v občini (Otočec, Brusnice in Stopiče). V prispevku se osredotočamo le na štiri šole v Novem mestu. Anketirani so bili učenci 3., 5. in 7. razreda, razen v primeru, ko je bil kateri od razredov odsoten. $\mathrm{V}$ tem primeru so bili anketirani učenci 6 . razreda. $\mathrm{Na}$ štirih večjih šolah v mestu sta bili anketirani po dve paralelki, na manjših šolah pa ena. Podatki v anketi leta 2016 so bili zbrani z ustnim anketiranjem učencev $\mathrm{v}$ razredih $-s$ postavljanjem vprašanj, dvigom ter štetjem rok in zapisom rezultatov. Anketarji so sledili vnaprej pripravljenemu obrazcu. $V$ anketi so bila zastavljena vprašanja o potovalnih načinih, ki so jih učenci uporabili na poti v šolo na dan anketiranja (poleti), o načinu, ki ga najpogosteje uporabijo pozimi, ter o želenem potovalnem načinu, če bi učenci lahko izbrali kateri koli potovalni način. Učenci so lahko predlagali spremembe in izboljšave za lažji prihod $\mathrm{v}$ šolo.

\subsection{Lastništvo osebnih avtomobilov}

Podatke o razvoju motorizacije oziroma lastništvu osebnih avtomobilov v Sloveniji in Mestni občini Novo mesto smo preračunali iz podatkov baze Statističnega urada Republike Slovenije (Surs), ki podatke objavlja v redni letni publikaciji Statistični letopis Republike Slovenije in na podatkovnem portalu SI-STAT. Stopnja motorizacije je izračunana na podlagi letnih podatkov o številu prebivalcev (na dan 1. 1. za predhodno leto) in številu osebnih avtomobilov (na dan 31. 12. za tekoče leto). Upošteva se število osebnih avtomobilov, registriranih v Sloveniji. V podatkih Sursa med osebne avtomobile spadajo vozila iz kategorije vozil M1 (motorna vozila z vsaj štirimi kolesi, namenjena za prevoz oseb, ki imajo poleg sedeža za voznika še največ osem sedežev) brez osebnih posebnih vozil (osebni avtomobil, ki je oblikovan za posebne namene, in ne za prevoz potnikov, npr. gasilska vozila, rešilni avtomobili, pogrebna vozila ipd.) (Statistični urad Republike Slovenije, 2016).

\subsection{Lokacija osnovnih šol in velikost šolskih okolišev}

V pričujočem prispevku nas je zanimalo, ali sta se v obravnavanem času v Novem mestu spremenila lokacija osnovnih šol in velikost šolskih okolišev, kar bi lahko bilo razlog za spremembe potovalnih navad osnovnošolcev. Spremembe smo ugotavljali $\mathrm{z}$ intervjuji odgovornih na obravnavanih šolah med pripravo celostne prometne strategije (Balant idr., 2017).

\subsection{Prometna ureditev $\mathbf{v}$ okolici osnovnih šol}

Z intervjuji odgovornih na obravnavanih šolah smo zbirali tudi podatke o morebitnih spremembah $\mathrm{v}$ prometnih ureditvah okolice šol (na primer nova prometna infrastruktura za motorni promet, kolesarje in pešce, umiritev prometa, parkirne površine za dostavo otrok in podobno) v zadnjih letih, ki bi lahko vplivale na potovalne navade osnovnošolcev. Tudi ti intervjuji so potekali med pripravo celostne prometne strategije (Balant idr., 2017). 


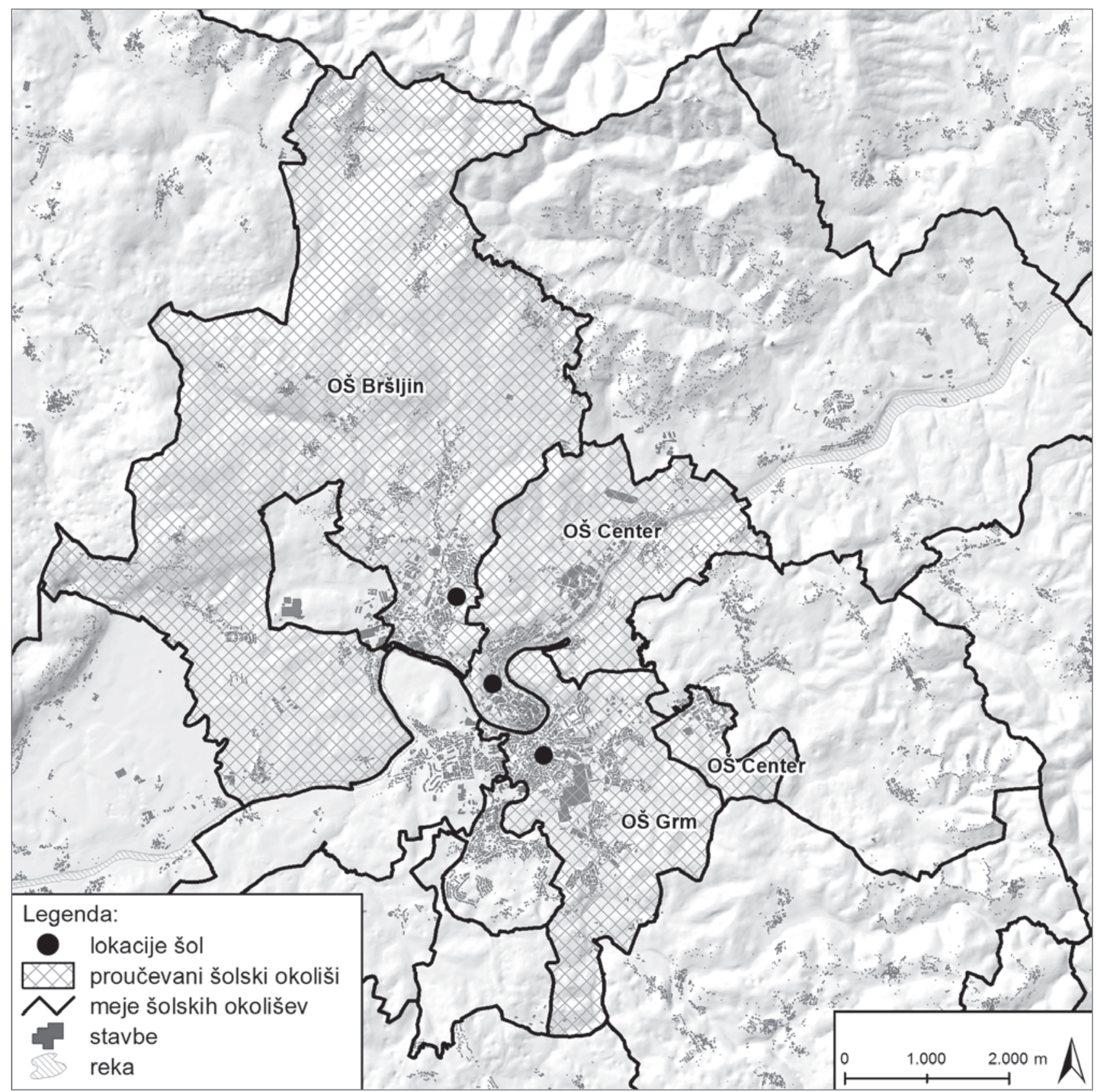

Slika 1: Obravnavane osnovne šole in njihovi šolski okoliši (avtor: Simon Koblar, prirejeno po: Geodetska uprava Republike Slovenije, 2017, in Copernicus, 2012)

\section{Rezultati}

\subsection{Potovalne navade osnovnošolcev}

\subsubsection{Način potovanja v šolo leta 1991}

Skoraj vsi osnovnošolci in srednješolci so leta $1991 \mathrm{v}$ šolo potovali aktivno, to je peš ali s kolesom. Pri poteh v šolo v 20 največjih slovenskih mestih je bil tega leta delež aktivnih potovalnih načinov kar $91 \%$ (pri poteh na delo le $61 \%$ ). Osem odstotkov šolarjev je uporabljalo avtobus, le odstotek šolarjev pa je bil pripeljan z osebnim avtomobilom. Deleži uporabe posameznih načinov so se med obravnavanimi 20 mesti precej razlikovali. $V$ celoti so prevladovale aktivne poti v šolo na Ravnah na Koroškem (100 \%), skoraj popolnoma pa so prevladovale v Domžalah in Kočevju (99 \%) ter Kamniku, Novi Gorici, Postojni in na Ptuju (98\%). V Novem mestu je bil delež aktivnih načinov $92 \%, 4 \%$ poti v šolo je bilo opravljenih z osebnim avtomobilom (največ med 20 največjimi slovenskimi mesti!), prav tako $4 \%$ pa z avtobusom. 


\subsubsection{Način potovanja v šolo leta 2001}

Leta 2001 so učenci 3., 5., in 7. razreda OŠ Center, Bršljiin in Grm v povprečju v šolo in iz šole večinoma pešačili (55\%), avtobus jih je uporabljalo $22 \%$, z osebnim avtomobilom pa je bilo pripeljanih $23 \%$ učencev. Kolesa ni uporabljal nobeden od sodelujočih $\mathrm{v}$ anketi. Način potovanja se precej razlikuje za poti v šolo od tistega iz šole. V šolo je zjutraj pešačila manj kot polovica učencev ( $46 \%$ ), z avtobusom se jih je pripeljal skoraj enak delež povprečju (21\%), z avtomobilom pa je bila pripeljana kar tretjina otrok (33\%). Pri poteh domov se je občutno zmanjšal delež uporabe osebnega avtomobila (13\%) in povečal delež hoje (63\%). Delež uporabe avtobusa je ostal podoben (23\%). Veliko staršev zjutraj izkoristi svoje poti na delo z osebnim avtomobilom še za prevoz otrok v šolo. Ker se delovni čas večine staršev ne ujema z urnikom otrok v šoli, je veliko učencev, ki so se v šolo pripeljali z osebnim avtomobilom, moralo domov peš ali z avtobusom. Zanimivo je, da na osnovnih šolah v Novem mestu leta 2001 nismo ugotovili kolesarjenja $\mathrm{v}$ šolo.

Potovalne navade so se med razredi precej razlikovale. Zakon o varnosti cestnega prometa predpisuje, da morajo imeti učenci 1. razreda na poti v šolo in domov spremstvo odrasle osebe. Zato ni presenetil nadpovprečen delež uporabe osebnega avtomobila med prvošolci v OŠ Center, za katere smo edino imeli zbrane podatke. Prevoz z avtomobilom je prevladoval tako na poti v šolo (63\%) kot na poti domov (58\%). Tako so leta 1991 med vsemi starostnimi skupinami le pri prvošolcih prevladovale poti z osebnim avtomobilom nad drugimi načini. Razlika deležev uporabe osebnega avtomobila med potmi $\mathrm{v}$ šolo in domov je bila majhna, kar kaže, da so se starši pri prvošolcih organizirali tako, da so jih tudi po pouku peljali domov. Dobra tretjina (34 \%) prvošolcev je v šolo pešačila, le redki pa so uporabili avtobus (3\%). Na poti domov ni nobeden izmed prvošolcev uporabil avtobusa, hodilo pa jih je precej več (42\%), in sicer zaradi manjših deležev voženj z osebnim avtomobilom in avtobusom. Pri višjih razredih je izstopal večji delež uporabe osebnega avtomobila pri tretješolcih ( $45 \%$ na poti v šolo in $20 \%$ na poti iz šole), ki se je pri višjih razredih zmanjšal zaradi hoje in ustalil.

Potovalne navade učencev so se pomembno razlikovale tudi med šolami. Najaktivnejše potovalne vzorce smo opazili pri učencih OŠ Grm, kjer je v šolo in iz šole v povprečju pešačilo $70 \%$ učencev ( $3 \% \mathrm{z}$ avtobusom in $27 \% \mathrm{z}$ avtomobilom). Sledi OŠ Center s 64-odstotnim deležem pešcev (15\% avtobus, $21 \%$ avtomobil), najmanj pešcev pa je bilo na OŠ Bršljin $(30 \%)$, kjer je z $49 \%$ prevladala uporaba avtobusa (avtomobil $21 \%)$. Za pojasnitev razlik med šolami smo analizirali vplive posameznih elementov fizične zgradbe prostora na značilnosti poti učencev. Ugotovili smo, da ima največji vpliv mre- ža oziroma razporeditev osnovnih šol, ki se posredno kaže v velikosti šolskih okolišev ter $\mathrm{v}$ gostoti prebivalcev in pozidave $\mathrm{v}$ njihovem zaledju. Gostejša mreža in manjši šolski okoliši z večjo gostoto prebivalcev in pozidave vplivajo na krajše poti v šolo in posledično na večji delež aktivnih poti v šolo. Pomemben dejavnik je tudi organizirani šolski prevoz, ki prevzema tako daljše poti, ki bi jih drugače pretežno opravili starši z uporabo osebnega avtomobila ali pa bi morali učenci dolge poti opraviti na nevarnejše aktivne načine, kot krajše poti (nad 1.000 m), ki jih učenci brez organiziranega šolskega prevoza prepešačijo. V Novem mestu smo ugotovili, da ima vsaka osnovna šola $\mathrm{v}$ zaledju največ $1.000 \mathrm{~m}$ vsaj eno zelo prometno cesto. Te so za varnost poti osnovnošolcev $\mathrm{v}$ šolo še posebno problematične. Hoja je resda najbolj trajnostni potovalni način, vendar je pri osnovnošolcih pomembnejša varnost, ki je pri organiziranih šolskih prevozih učencev večja.

S stališča trajnostnega prometa je verjetno najslabša redka mreža šol $s$ tako velikostjo šolskih okolišev, ki še ne zadošča za organizacijo šolskega prevoza (razdalje do $4 \mathrm{~km}$ ). V njih so mnogi učenci vezani na jutranje prevoze $s$ trajnostno najbolj spornim prevoznim sredstvom - osebnim avtomobilom -, na poti domov pa so pogosto prepuščeni sami sebi, kar je sporno predvsem zaradi njihove varnosti (Plevnik, 2002: 188-189).

\subsubsection{Način potovanja v šolo leta 2016}

Pri podatkih za leto 2016 zaradi primerljivosti s prejšnjim časovnim prerezom obravnavamo tri osnovne šole iz Novega mesta, ki smo jih vključili v raziskavo leta 2001 (Center, Grm in Bršljin), čeprav je anketa vključevala še eno osnovno šolo iz mesta (Šmihel) in tri osnovne šole iz manjših naselij v občini (Otočec, Brusnice in Stopiče).

V povprečju so leta 2016 več kot polovico učencev 3., 5. in 7. razreda ( $53 \%$ ) v šolo pripeljali starši z avtomobilom (leta 2001 v šolo $33 \%$ ). Skoraj 32 \% učencev je pešačilo (leta $200146 \%$ ), $21 \%$ se jih je pripeljalo z avtobusom (enak delež kot leta 2001) in dober odstotek $s$ kolesom (0 \% leta 2001). Učence smo povprašali, ali pozimi spremenijo potovalni način. Rezultati ne kažejo večjih sprememb v potovalnih navadah, razen večjega deleža voženj z avtobusom (28 \%), zaradi hoje (27\%) in deloma vožnje z avtomobilom (44\%). Aktivno torej v šolo prihaja tretjina učencev v Novem mestu (53\% leta 2001), dve tretjini pa sta pripeljani (polovica leta 2001), večinoma z osebnim avtomobilom. Primerjava med razredi je pokazala podobne značilnosti kot leta 2001. Največji delež prevozov z avtomobili smo ugotovili pri tretješolcih ( $58 \%$ ), ki je upadal pri petošolcih (46\%) in dosegel najmanjši delež pri srednješolcih (30 \%). Nasprotno je v šolo aktivno prišlo največ sedmošolcev (41 \% peš, $3 \% \mathrm{~s}$ kolesom), precej manj petošolcev (31 \% peš, $1 \% \mathrm{~s}$ kolesom) in le petina tretješolcev ( $20 \%$ peš). 


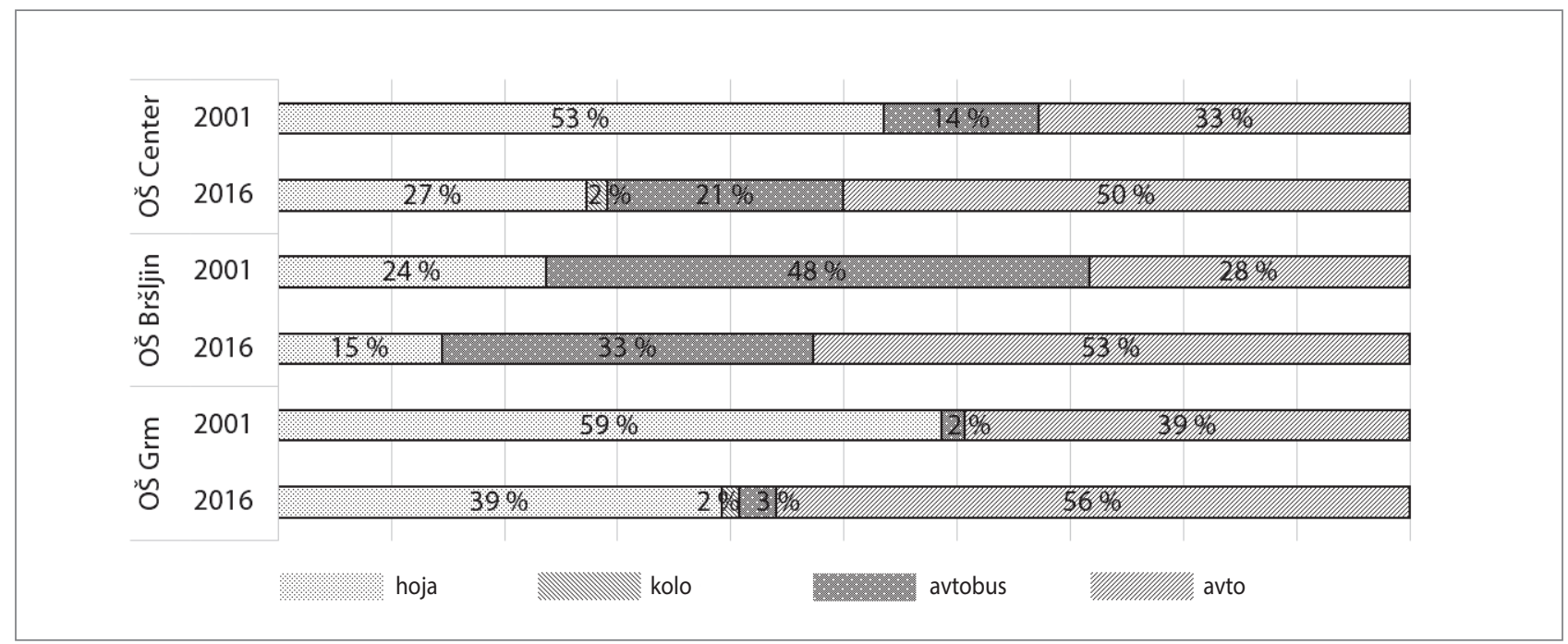

Slika 2: Primerjava potovalnih navad za prihode v šolo po šolah in letih (avtor: Luka Mladenovič, prirejeno po: Zavod Republike Slovenije za statistiko, 1992; Plevnik, 2002; Balant idr., 2017)

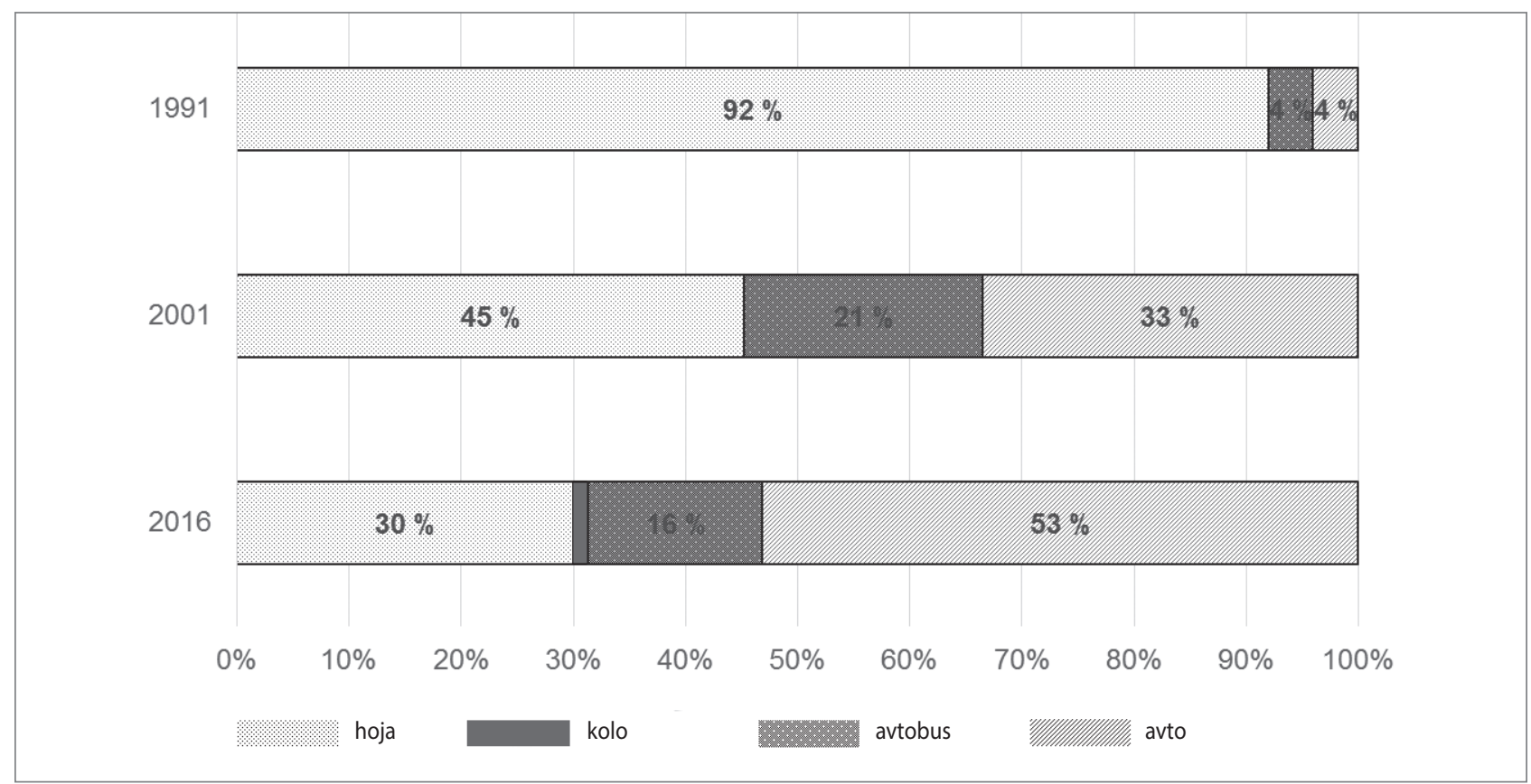

Slika 3: Skupne spremembe potovalnih navad (avtor: Simon Koblar)

Znova so se pomembno razlikovale potovalne navade učencev med šolami. Enako kot leta 2001 smo tudi leta 2016 najaktivnejše potovalne vzorce ugotovili pri učencih OŠ Grm, kjer je v šolo v povprečju pešačilo $39 \%$ (leta $200170 \%$ učencev), s kolesom pa sta se vozila slaba $2 \%$ (leta 2001 nihče). Pomembno se je povečal delež avtomobilskih prevozov - s $27 \%$ leta 2001 na $56 \%$ leta 2016. Delež uporabnikov avtobusa je ostal nespremenjen (3\%). Na OŠ Center se je delež aktivni poti več kot prepolovil, in sicer s $64 \%$ pešcev leta 2001 na $27 \%$ pešcev in $2 \%$ kolesarjev v letu 2016. Delež uporabe avtomobila je poskočil s $27 \%$ na $50 \%$, delež uporabnikov avtobusa pa s $16 \%$ na $21 \%$. Tudi na OŠ Bršljin se je delež hoje v 15 letih prepolovil, s $30 \%$ na $15 \%$, še zmeraj pa nihče ni uporabljal kolesa. Pomembno se je zmanjšal tudi leta 2001 prevladujoč način - delež avtobusnih voženj je upadel z $49 \%$ na $33 \%$. Na tej šoli se je delež uporabe avtomobila najbolj povečal, in sicer z $21 \%$ v letu 2001 na 53 \% leta 2016.

V anketi leta 2016 smo dodali vprašanje o tem, kako si učenci želijo potovati v šolo. Želje otrok so v popolnem nasprotju z njihovim običajnim ravnanjem in v skladu s prizadevanji za aktivno mobilnost - večina otrok želi v šolo s kolesom (40\%) in peš ( $40 \%)$. Z avtomobilom si v osnovno šolo želi prihajati le $12 \%$ učencev, $\mathrm{z}$ avtobusom pa $7 \%$. Predvsem glede kolesarjenja je razlika med dejanskim stanjem in željami tako velika, da bi bilo smiselno raziskati razloge, ki učencem preprečujejo kolesarjenje $\mathrm{v}$ šolo, in jih začeti postopno odpravljati. 


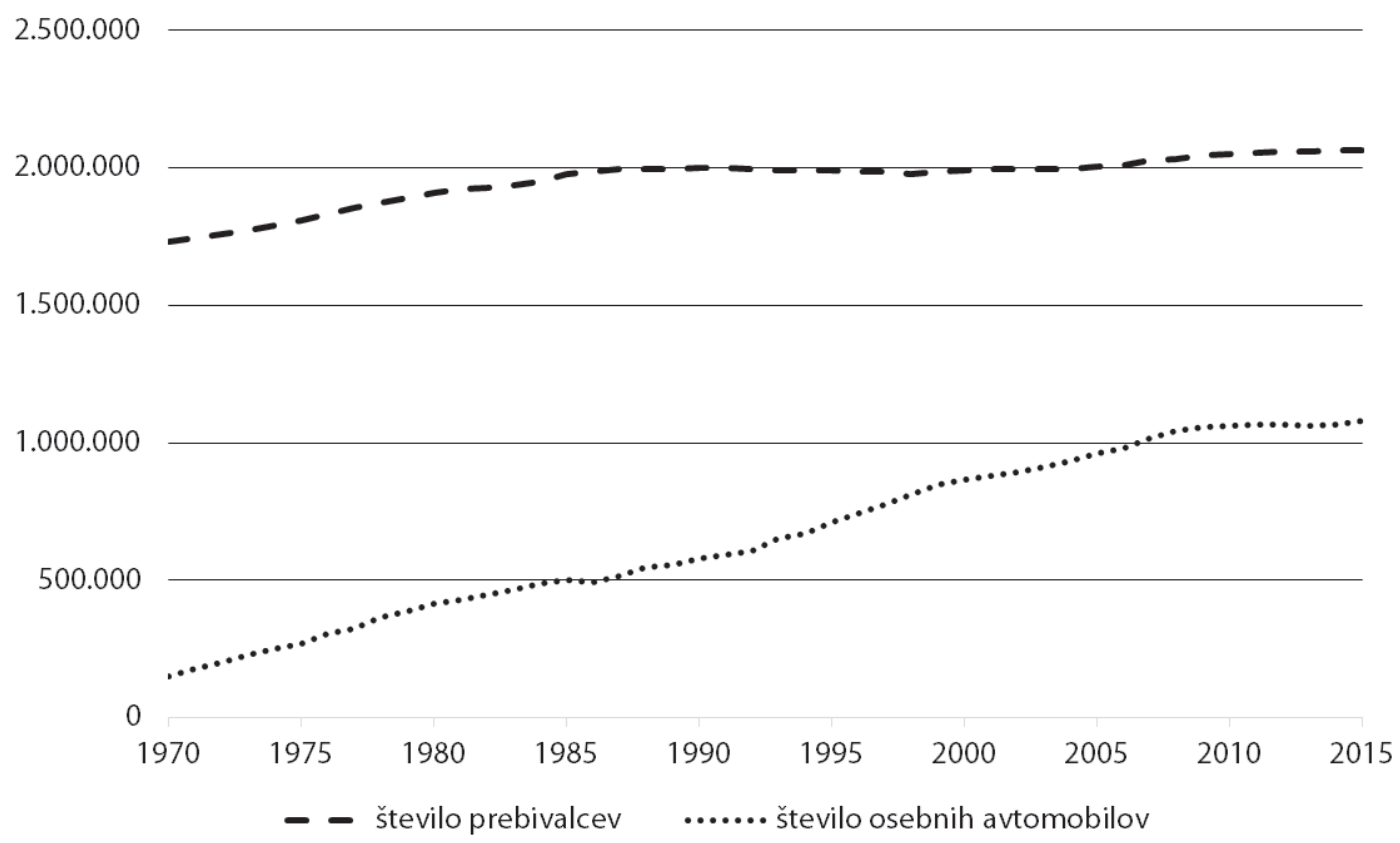

Slika 4: Število osebnih avtomobilov in prebivalcev v Sloveniji med letoma 1970 in 2015 (vir: Plevnik, 2016)

Potovalne značilnosti osnovnošolcev v osnovnih šolah v Novem mestu so zelo podobne rezultatom podobnih novejših raziskav drugje po Sloveniji. Učenci v šolah, ki so v letu 2015 sodelovali v državni kampanji Prometna kača, so imeli pred kampanjo podobne potovalne vzorce, kot smo jih ugotovili v Novem mestu. Aktivno je v šolo prihajalo $29 \%$ učencev (od tega $3 \%$ $s$ kolesom). Velika večina je bila v šolo pripeljanih $-42 \%$ z avtomobilom in $29 \% \mathrm{z}$ javnim prevozom (Moscholidou in Colclough, 2017).

\subsection{Lastništvo osebnih avtomobilov}

Razvoj motorizacije je v Sloveniji v zadnjih desetletjih doživel še posebej močan razmah. Med letoma 1970 in 2015 se je število osebnih avtomobilov v Sloveniji povečalo kar sedemkrat in preseglo 1,070.000. Stopnja motorizacije je bila 2015523 osebnih avtomobilov na 1.000 prebivalcev, kar je skoraj $50 \%$ več kot leta 1995 (Plevnik, 2016). S tem se Slovenija uvršča med države z največjim povečanjem lastništva osebnih avtomobilov, saj stopnja motorizacije že leta močno presega povprečje novih držav članic EU in držav kandidatk EU ter številnih gospodarsko razvitejših držav, na primer skandinavskih.

Mestna občina Novo mesto v stopnji motorizacije že od leta 2001 presega slovensko povprečje, kjer je najvišja stopnja motorizacije v občinah na zahodnem delu države. Leta 2006 je stopnja motorizacije presegla 500 vozil na 1.000 prebivalcev, kar pomeni, da je imel vsak drugi prebivalec v lasti osebni avtomobil. Leta 2015 je bila stopnja motorizacije 541 vozil na 1.000 prebivalcev (v celotni Sloveniji: 523).

\subsection{Lokacija osnovnih šol in velikost šolskih okolišev}

Za pojasnitev razlik med šolami smo že po prvi anketi leta 2001 analizirali posamezne elemente fizične zgradbe mesta in njihov vpliv na značilnosti poti učencev. Ugotovili smo, da ima največji vpliv mreža oziroma razporeditev osnovnih šol, ki se posredno kaže $\mathrm{v}$ velikosti šolskih okolišev ter $\mathrm{v}$ gostoti prebivalcev in pozidave v njihovem zaledju. Gostejša mreža in manjši šolski okoliši z večjo gostoto prebivalcev in pozidave vplivajo na krajše poti v šolo in posledično na večji delež aktivnih poti v šolo. Po drugi strani imajo večji šolski okoliši, kot je OŠ Bršljin, že zaradi zakonskih zahtev po zagotavljanju prevoza bolj razvejano mrežo šolskih avtobusnih prevozov, kar vpliva na večji delež uporabe avtobusa. Dodatno smo preverili spremembe v lokaciji šol in velikosti šolskih okolišev po letu 2001. Glavna sprememba je bila gradnja nove OŠ Drska leta 2002, ki je prevzela del šolskega okoliša OŠ Šmihel in ni vplivala na šolske okoliše v anketi obravnavanih šol. Zato sprememba $\mathrm{v}$ gostoti mreže osnovnih šol in njihovih šolskih okolišev ni vplivala na potovalne navade učencev obravnavanih šol.

\subsection{Prometna ureditev $v$ okolici osnovnih šol}

Prometno ureditev v okolici šol smo preverjali s terenskimi ogledi med pripravo celostne prometne strategije za MO Novo mesto, spremembe po letu 2001 pa preverjali v intervjujih z odgovornimi za prometno varnost na obravnavanih osnovnih šolah. Vse obravnavane šole se redno ukvarjajo $\mathrm{z}$ varnimi pot- 
mi v šolo in z ukrepi za njihovo zagotovitev. Šole imajo načrt varnih poti v šolo z evidenco nevarnih mest, ki jih odpravljajo $\mathrm{v}$ sodelovanju z mestno občino. V okolici vseh šol so bili po letu 2001 izvedeni številni ukrepi za varnost otrok, predvsem na področju umirjanja prometa in varnega prečkanja cestišč. Tovrstni ukrepi so usmerjeni v povečanje varnosti otrok v prometu in bi lahko prispevali k povečanju deleža aktivnih poti v šolo. Šole s podporo strokovnih organizacij redno organizirajo izobraževalne in promocijske dogodke, povezane s prometno varnostjo, predvsem ob začetku šolskega leta.

\section{Razprava}

Rezultati primerjave treh časovnih prerezov načinov poti v osnovne šole v Novem mestu in primerjava s podatki iz drugih šol po Sloveniji kažejo na velike spremembe v potovalnih navadah mladih prebivalcev naših mest in posledično njihovih staršev. Ključen prispevek tega članka je kvantificiranje obsega trenda spremembe potovalnih navad za prihod osnovnošolskih otrok $\mathrm{v}$ šolo. Trend smo opazovali strokovnjaki različnih področij in nanj opozarjali, a zaradi neobstoja sistematičnega zbiranja podatkov o potovalnih navadah prebivalcev, $\mathrm{v}$ tem primeru osnovnošolcev, nismo mogli opredeliti, $\mathrm{v}$ kakšnem obsegu se je ta sprememba dejansko odvila. $\mathrm{Z}$ raziskavo nam je uspelo zbrati podatke, primerljive z metodo, uporabljeno 2001, kar nam prvič na tem področju daje na voljo dva časovna prereza.

Leta 1991 je v slovenskih mestih v šolo aktivno (peš ali s kolesom) prišlo več kot $90 \%$ otrok, v Novem mestu pa je delež aktivnih potovanj leta 2001 padel na manj kot polovico, do leta 2016 pa na tretjino. Podatki za 31 drugih šol po Sloveniji za leto 2015 potrjujejo, da je ta skrb vzbujajoči trend značilen za celotno državo. Podobne trende so ugotovili tudi v številnih drugih razvitih državah po svetu. V Švici se je aktiven prihod učencev v šolo med letoma 1994 in 2005 zmanjšal z $78 \%$ na $71 \%$ zaradi uporabe osebnega avtomobila. Zmanjšal se je predvsem delež tistih, ki so v šolo kolesarili, medtem ko je delež hoje ostal velik. Avtorji zmanjšanje pripisujejo predvsem pomembnemu povečanju dostopnosti lastništva osebnega avtomobila v tem obdobju (Grize idr., 2010). Podatki za Veliko Britanijo kažejo, da je delež otrok med 5. in 10. letom starosti, ki so v letih 1991, 1993 in 2002 pešačili v šolo, padel s $60 \%$ na $51 \%$ (Department for Transport, 2004), v letu 2014 pa že na 46 \% (Department for Transport, 2014). Vzporedno $s$ tem se je delež tistih, ki so v šolo pripeljani z avtomobilom, povečal z $29 \%$ na $46 \%$ (Department for Transport, 2014). V Združenih državah Amerike je zmanjšanje zaradi zgodnje in še bolj intenzivne motorizacije na nekaterih območjih še večje. Kirsten Davison s sodelavci (2008) za zvezno državo Washington poroča o zmanjšanju aktivnega prihoda v šolo otrok med 5. in 15. letom starosti z 48 \% v letu 1969 na $16 \%$ v letu 2001.
Razlogi za obravnavane spremembe potovalnih navad otrok so večplastni in v literaturi lahko najdemo več nasprotujočih si razlag za te spremembe. Poleg osnovnega dejstva, tj. večje dostopnosti osebnega avtomobila in s tem povečanega lastništva in uporabe, ter oddaljenosti bivališča od šole, ki omejuje uporabo aktivnih oblik prihoda v šolo (Chillon idr., 2011), se v literaturi pojavljajo številni drugi dejavniki, ki vplivajo na izbor načina prihoda v šolo. Pogosto kot oviro za aktivni prihod starši navajajo prometno varnost oziroma občutek ogroženosti pešcev ali kolesarjev v prometu (Loukaitou-Sideris, 2006; Ahlport idr., 2008; Dimaggio, 2013). Ta je povezana $s$ hitrostjo in količino vozil ter razpoložljivimi površinami za pešce. Študija iz Švice (Grize idr., 2010) je pokazala, da so pomembne ovire za hojo in kolesarjenje poleg razdalje tudi prečkanja pomembnejših cest. Davisonova s sodelavci (2008) med te ovire dodaja še razlike med ruralnim in urbanim okoljem ter vremenske vplive.

Leticia Grize s sodelavci (2010) trdi, da je izbor potovalnega načina posledica družinskega procesa odločanja, na katero vplivajo povezovanje poti v šolo $s$ potmi na delo, udobje, skrb staršev glede prometne varnosti ter družbena in kulturna sprejemljivost posameznega potovalnega načina. Davisonova s sodelavci (2008) kot pomembne dejavnike pri izboru potovalnega načina navaja delovni urnik staršev in urnik otrokovih popoldanskih aktivnosti, ali so starši aktivno prihajali v šolo, ko so bili sami otroci, ali starši trenutno hodijo ali kolesarijo na delo, ali starši cenijo telesno aktivnost in spremljajoče družbene interakcije svojih otrok ter kulturno in družbeno sprejemljivost posameznega potovalnega načina. Grizetova s sodelavci (2010) pojasnjuje razlike v kulturni in družbeni sprejemljivosti posameznega potovalnega načina $\mathrm{z}$ velikimi razlikami v aktivnem potovanju v šolo med nemško ( $80 \%)$, francosko (56\%) ali italijansko (52\%) govorečimi deli Švice.

Rezultati v Sloveniji pritrjujejo delu ugotovitev iz tujine. Velike spremembe v potovalnih vzorcih otrok časovno sovpadajo z intenzivno motorizacijo slovenskih mest, ki je dosegla večje razsežnosti kot v marsikateri razvitejši državi. Povečano lastništvo avtomobilov se kaže v njihovi povečani rabi. Delo na večjem številu celostnih prometnih strategij kaže, da se le večja mesta v Sloveniji (Ljubljana in Maribor) uspešno spoprijemajo $\mathrm{z}$ rastjo osebnega motornega prometa, $\mathrm{v}$ majhnih in srednje velikih mestih pa njihov delež večinoma še narašča. V Novem mestu smo ugotovili, da v izboru potovalnega načina močno prevladuje osebni avtomobil (78 \%), sledijo hoja (9\%), javni prevoz (8 \%) in kolesa (manj kot $1 \%$ ) (Balant idr. 2017). V Ljubljani so bili leta 2015 deleži precej manjši pri uporabi osebnih avtomobilov (42\%). Ljudje veliko več hodijo (35\%), kolesarijo (11\%) in uporabljajo avtobus (13\%) (Mestna občina Ljubljana, 2017). 


\section{Sklep}

Če smo lahko 2001 ugotavljali možno povezanost med dolžino poti v šolo in deležem aktivnih poti, ta povezanost vse bolj slabi. Otroci so v vedno večjem deležu v avtomobilih pripeljani na vse krajše razdalje (tudi manj kot $1.000 \mathrm{~m}$ ), ki bi jih z lahkoto lahko opravili aktivno.

Del vzrokov obravnavanih trendov pojasnjujejo opozorila tujih strokovnjakov, da je treba zamenjati paradigmo prometne varnosti, ker naj bi intenzivno ukvarjanje s prometno varnostjo v okvirih veljavne paradigme lahko vplivalo na zmanjšanje aktivnih načinov potovanj. Todd Litman (2017) ugotavlja, da veljavna paradigma prometne varnosti predpostavlja, da je uporaba motornih vozil na splošno najvarnejša in da so nesreče posledica tveganega ravnanja določenih skupin ljudi, kot so vožnja mladih ali starejših, motnje med vožnjo (npr. uporaba telefona) ter neuporaba varnostnega pasu ali čelade pri kolesarjih. Zato se veljavni pristop usmerja na ciljne pristope in programe za zmanjšanje specifičnih tveganj (npr. zmanjšanje hitrosti, preganjanje uporabe telefona med vožnjo, uporaba varnostnega pasu, spodbujanje varnega kolesarjenja z uporabo čelade, krepitev vidnosti ogroženih udeležencev $\mathrm{v}$ prometu in podobno). Nova paradigma prometne varnosti izhaja iz predpostavke, da vsaka uporaba prevoznega sredstva predstavlja določeno tveganje in da je večina voznikov izpostavljena majhnim tveganjem, ki lahko privedejo do nesreče. Zato vsi pristopi, ki ne zmanjšujejo prometa motornih vozil, povečujejo tudi nevarnost nesreč, nasprotno pa pristopi zmanjševanja motornega prometa in spodbujanja alternativ odpravljajo tveganja nesreč. Nova paradigma gradi tudi na spoznanju, da je nesmotrno zmanjševanje uporabe osebnih motornih vozil brez vzpostavljanja kakovostnih alternativ. Nov pristop tako razširja nabor možnih ukrepov za izboljšanje prometne varnosti in vključuje več celostnega prometnega načrtovanja, ki se ukvarja $\mathrm{z}$ vsemi potovalnimi načini, pa tudi več upravljanja mobilnosti in ukrepov, integriranih s prostorskim načrtovanjem (Litman, 2017).

Ukvarjanje s prometno varnostjo na slovenskih osnovnih šolah je v skladu s staro paradigmo. Čeprav gre za pomembno, centralno vodeno in odlično organizirano področje, ki daje dobre rezultate na področju prometne varnosti, stara paradigma očitno prispeva $\mathrm{k}$ upadu aktivne mobilnosti med osnovnošolci z vsemi v uvodu navedenimi negativnimi posledicami na njihovo zdravje. Ukvarjanje s prometno varnostjo v naših šolah se osredotoča na zmanjšanje tveganega ravnanja voznikov $\mathrm{v}$ okolici šol in odpravljanje konfliktov med motoriziranimi in aktivnimi udeleženci v okolici šol. Toda tak pristop hkrati vzpostavlja razmere in prepričanje med starši, da je za otroke najbolj varno, če jih $\mathrm{v}$ šolo pripeljejo z osebnim avtomobilom. Tako razumevanje v kombinaciji z zagotavljanjem parkirišč za varno dostavo otrok in za uslužbence šole (trend, ki smo ga opazili v vseh Celostnih prometnih strategijah v Sloveniji), povečuje obseg motornega prometa v neposredni okolici šol, predvsem $\mathrm{v}$ jutranji konici, $s$ tem pa povečuje tveganje novih nesreč. Gre za paradoks, ko veljavna paradigma prometne varnosti kljub drugačnemu namenu ustvarja prometno nevarne situacije v okolici šol in ogroža varnost vrstnikov in $s$ tem povečuje delež otrok, ki prihajajo $\mathrm{v}$ šolo varno, a nezdravo - v osebnem avtomobilu.

Nabor rešitev podaja predvsem nova paradigma prometne varnosti. Osredotočenost ukvarjanja s prometno varnostjo se mora $\mathrm{z}$ varne vožnje preusmeriti na njeno zmanjševanje $\mathrm{v}$ okolici šol. Ukvarjanje z mobilnostjo otrok mora postati del celostnega prometnega načrtovanja, ki naj si prizadeva za zmanjšanje in umirjanje osebnega motornega prometa v okolici šol z vzpostavljanjem razmer, ki niso prijazne uporabi osebnih motornih vozil in spodbujajo varno rabo aktivnih alternativ. Omejevati je treba dostope in parkiranje osebnih vozil, tudi za zaposlene $\mathrm{v}$ šolah. Ob fizični preureditvi okolice šol je veliko energije treba usmeriti v upravljanje mobilnosti in spreminjanje navad vseh - otrok, staršev in zaposlenih na šolah. Upravljanje mobilnosti je koncept, ki promovira trajnostni promet in aktivno mobilnost ter uravnava povpraševanje po uporabi avtomobila na način, da spreminja stališča in potovalne navade prebivalcev. Njegovo bistvo so mehki ukrepi, kot so informiranje in komuniciranje, organizacija storitev in koordiniranje dejavnosti različnih partnerjev. Mehki ukrepi največkrat okrepijo učinkovitost trdih ukrepov v prometu (npr. nove površine za pešce ali kolesarske steze, tudi odprava dostopa ali ukinitev parkirnih mest). Mehki ukrepi (v primerjavi s trdimi) navadno ne zahtevajo velikih denarnih vložkov in imajo pogosto zelo ugodno razmerje med koristmi in stroški. Tipični primer upravljanja mobilnosti je pobuda Prometna kača (Moscholidou in Colclough, 2017), ki je tudi v Sloveniji potrdila, da je vračanje k večji aktivni mobilnosti otrok mogoče in nujno potrebno.

\section{Aljaž Plevnik \\ Urbanistični inštitut Republike Slovenije, Ljubljana, Slovenija \\ E-naslov:aljaz.plevnik@uirs.si}

\section{Mojca Balant}

Urbanistični inštitut Republike Slovenije, Ljubljana, Slovenija

E-naslov:mojca.balant@uirs.si

Luka Mladenovič

Urbanistični inštitut Republike Slovenije, Ljubljana, Slovenija

E-naslov: luka.mladenovic@uirs.si

\section{Viri in literatura}

Ahlport, K. N., Linnan, L., Vaughn, A., Evenson, K. R., in Ward, D. S. (2008): Barriers to and facilitators of walking and bicycling to school: formative results from the non-motorized travel study. Health Educa- 
tion \& Behavior: the Official Publication of the Society for Public Health Education, 35(2), str. 221-244. DOI: 10.1177/1090198106288794

Balant, M., Mladenovič, L., in Plevnik, A. (2017): Celostna prometna strategija Mestne občine Novo mesto: enostavne poti do živahnih središč. Novo mesto, Mestna občina Novo mesto.

Chillón, P., Evenson, K. R., Vaughn, A., in Ward, D. S. (2011): A systematic review of interventions for promoting active transportation to school. The International Journal of Behavioral Nutrition and Physical Activity, 8(10), str. 1-17. DOI: 10.1186/1479-5868-8-10

Copernicus (2012): Corine land cover, verzija 18.5.1. Dostopno na: http://land.copernicus.eu/pan-european/corine-land-cover/clc-2012 (sneto 12. 6. 2017).

Davison, K. K., Werder, J. L., in Lawson, C. T. (2008): Children's active commuting to school: current knowledge and future directions. Preventing Chronic Disease, 5(3). Dostopno na: http://www.cdc.gov/pcd/ issues/2008/jul/07_0075.htm (sneto 29. 5. 2017).

Department for Transport (2004): Transport Statistics Bulletin. National Travel Survey: 2002 (revised July 2004). London.

Department for Transport (2014): National Travel Survey 2014: Travel to school. London.

Dimaggio, C., in Li, G. (2013): Effectiveness of a safe routes to school program in preventing school-aged pedestrian injury. Pediatrics, 131(2), str. 290-296. DOI: 10.1542/peds.2012-2182

Grize, L., Bringolf-Isler, B., Martin, E., in Braun-Fahrländer, C. (2010): Trend in active transportation to school among Swiss school children and its associated factors: three cross-sectional surveys 1994, 2000 and 2005. The International Journal of Behavioral Nutrition and Physical Activity, 7(28), str. 1-8. DOI: 10.1186/1479-5868-7-28

Jeriček Klanšček, H., Roškar, S., Koprivnikar, H., Pucelj, V., Bajt, M., in Zupanič, T. (2011): Neenakosti v zdravju in z zdravjem povezanih vedenjih slovenskih mladostnikov. Ljubljana, Inštitut za varovanje zdravja Republike Slovenije.

Kobe Tavčar, A. (2015): Izvajanje celostne prometne strategije - varne poti. Prispevek je bil predstavljen na simpoziju v okviru projekta TRADOMO: Potujmo drugače in regionalni konferenci projekta PUMAS, ki je potekala 22. aprila 2015 v Šempetru. Tipkopis.

Litman, T. (2017): The new traffic safety paradigm. Victoria Transport Policy Institute. Victoria. Dostopno na: http://www.vtpi.org/ntsp.pdf (sneto 21. 5. 2017).

Loukaitou-Sideris, A. (2006): Is it safe to walk? Neighborhood safety and security considerations and their effects on walking. Journal of Planning Literature, 20(3), str. 219-232. DOI: 10.1177/0885412205282770

Ministrstvo za zdravje (2015): Resolucija o nacionalnem programu o prehrani in telesni dejavnosti za zdravje 2015-2025. Ministrstvo za zdravje, Ljubljana. Dostopno na: http://www.mz.gov.si/fileadmin/mz.gov.si/ pageuploads/javna_razprava_2015/Resolucija_o_nac_programu_prehrane_in_in_tel_dejavnosti_jan_2015.pdf (sneto 28. 5. 2017).

Mestna občina Ljubljana (2017): Celostna prometna strategija Mestne občine Ljubljana; Predlog. Ljubljana, Ljubljanski urbanistični zavod, d. d., in Regionalna razvojna agencija Ljubljanske urbane regije.

Moscholidou, l., in Colclough, J. (2017): The traffic snake game network. Final results report. EU IEE project. Dostopno na: http://www.trafficsnakegame.eu/wp-content/uploads/2014/05/D5.5-Final-Evaluation-ReportFebruary-2017.pdf (sneto 21. 5. 2017).

Plevnik, A. (2002): Povezanost fizične zgradbe mest in prometa v mestih v Sloveniji. Doktorska disertacija. Ljubljana, Filozofska fakulteta, Oddelek za geografijo.
Plevnik, A. (2016): Lastništvo osebnih avtomobilov. Ljubljana, Ministrstvo za okolje in prostor, Agencija za okolje Republike Slovenije. Dostopno na: http://kazalci.arso.gov.si/?data=indicator\&ind_id=756 (sneto 15. 6. 2017).

Polič, M., Zabukovec, V., Žlender, B., in Markl, M. (2001): Državne ceste in prometna varnost učencev - OŠ "Center" Novo mesto. Poročilo o tretji fazi. Ljubljana, Filozofska fakulteta, Oddelek za psihologijo, Znanstveni inštitut.

Geodetska uprava Republike Slovenije (2017): Portal prostor. Dostopno na: http://www.e-prostor.gov.si/brezplacni-podatki/ (sneto 12. 9. 2017)

Schoeppe, S., Duncan, M. J., Badland, H., Oliver, M., in Curtis, C. (2013): Associations of children's independent mobility and active travel with physical activity, sedentary behaviour and weight status: A systematic review. Journal of Science and Medicine in Sport, 16(4), str. 312-319. DOI: 10.1016/j.jsams.2012.11.001

Starc, G. (2014): Zdrav življenjski slog $360^{\circ}$ za dobro otrok. V: Scagnetti, N. (ur). Skupaj za boljše zdravje otrok in mladostnikov - ohranjanje in zagotavljanje enakih možnosti, str. 12-19. Ljubljana, Nacionalni inštitut za javno zdravje.

Statistični urad Republike Slovenije (2016): Prve registracije cestnih vozil glede na vrsto vozila, Slovenija, mesečno. Ljubljana. Dostopno na: http://pxweb.stat.si (sneto 21. 5. 2017).

Strel, J., Starc, G., in Kovač, M. (2011): SLOFIT sistem - analiza telesnega in gibalnega razvoja otrok in mladine slovenskih osnovnih in srednjih šol v šolskem letu 2010/2011. Ljubljana, Univerza v Ljubljani, Fakulteta za šport.

UK active (2016): Active travel. UK active's blueprint for an active Britain. London. Dostopno na: http://www.ukactive.com/downloads/managed/Blue_print_PDF/active_travel_online.pdf (sneto 28. 5. 2017).

Van Sluijs, E. M., Fearne, V. A., Mattocks, C., Riddoch, C., Griffin, S. J., in Ness, A. (2009): The contribution of active travel to children's physical activity levels: Cross-sectional results from the ALSPAC study. Preventive Medicine, 48(6), str. 519-524. DOI: 10.1016/j.ypmed.2009.03.002

Zavod Republike Slovenije za statistiko (1992): Rezultati popisa 1991. Obdelani osnovni podatki. Ljubljana. 